\title{
Mitotic Spindle Assembly in Land Plants: Molecules and Mechanisms
}

\author{
Moé Yamada and Gohta Goshima* \\ Graduate School of Science, Division of Biological Science, Nagoya University, Furo-cho, Chikusa-ku, \\ Nagoya 464-8602, Japan; yamada.moe@a.mbox.nagoya-u.ac.jp \\ * Correspondence: goshima@bio.nagoya-u.ac.jp; Tel.: +81-52-788-6175; Fax: +81-52-788-6174 \\ Academic Editor: J. Richard McIntosh \\ Received: 1 October 2016; Accepted: 8 January 2017; Published: 25 January 2017
}

\begin{abstract}
In textbooks, the mitotic spindles of plants are often described separately from those of animals. How do they differ at the molecular and mechanistic levels? In this chapter, we first outline the process of mitotic spindle assembly in animals and land plants. We next discuss the conservation of spindle assembly factors based on database searches. Searches of $>100$ animal spindle assembly factors showed that the genes involved in this process are well conserved in plants, with the exception of two major missing elements: centrosomal components and subunits/regulators of the cytoplasmic dynein complex. We then describe the spindle and phragmoplast assembly mechanisms based on the data obtained from robust gene loss-of-function analyses using RNA interference (RNAi) or mutant plants. Finally, we discuss future research prospects of plant spindles.
\end{abstract}

Keywords: mitosis; kinetochore; centrosome; dynein; kinesin; augmin; gamma-tubulin; Arabidopsis thaliana; Physcomitrella patens; Haemanthus

\section{Microscopic Overview of the Spindle Assembly}

Mitotic spindle formation involves several key events, such as microtubule (MT) generation, bipolarity establishment, pole focusing, length control, and chromosome capture/alignment. Since the early days of spindle research, plant spindles have often been described separately from those of animal cells, perhaps owing to the apparent differences in their overall structure [1,2]. Most noticeably, land plants lack centrosomes, the dominant MT nucleating and organising centre in animal somatic cells; the metaphase spindle is generally barrel-shaped without a single focusing point at the pole (Figure 1). In the later stages of mitosis, plant cells uniquely assemble phragmoplasts that are MT arrays for cell plate material deposition. How, then, do land plant and animal spindles differ at the molecular level? In this chapter, we first outline the process of mitotic spindle assembly in animals and plants before discussing the molecular factors involved in this process.

\subsection{Mitotic Spindle Assembly in Animals}

The start of mitosis in animal somatic cells is characterised by the maturation of centrosomes during prophase. Centrosomes serve as the dominant MT generation sites as well as MT organising centres during spindle assembly [3]. After nuclear envelope breakdown (NEBD), two additional mechanisms operate to produce more MTs [4,5]. One is chromosome-mediated nucleation, in which a chromosome-associated protein activates the MT nucleation/stabilisation machinery around the chromosomes [6]. The other is MT-dependent MT nucleation, where new MTs are nucleated in a branching fashion from the existing MTs, such as those nucleated via the centrosomal or chromosomal pathway [7]. In some cell types, these three pathways act in concert, whereas in others, one or two pathways do not play major roles [8]. Regardless of their source, MTs are oriented in a bipolar manner by the action of MT-based motor proteins and through stable bipolar association with 
kinetochore MTs [9]. Two poles of the metaphase spindle are well focused as spindle MTs remain associated with the centrosome at the pole or crosslinked with each other by motors and MAPs [10,11]. Regulators of MT dynamics also play critical roles in spindle morphogenesis; alteration of MT dynamics affects the length and pole organisation of the metaphase spindle [12]. During prometaphase and metaphase, sister kinetochores are bioriented and attach to the plus end of MTs; completion of this process is essential for equal segregation of sister chromatids into two daughter cells. In addition, a defect in the kinetochore-MT attachment causes force imbalance in the spindle that affects spindle length. During anaphase, kinetochore MTs are depolymerised, whereas interpolar MTs elongate. In addition, MTs are de novo generated by the actions of three MT generating pathways that also operate during pre-anaphase [13]. Motor- and MAP-dependent crosslinking of those MTs at the midzone leads to the appearance of the characteristic central spindle structure during anaphase that is required for subsequent cytokinesis [14].

A Animal cell

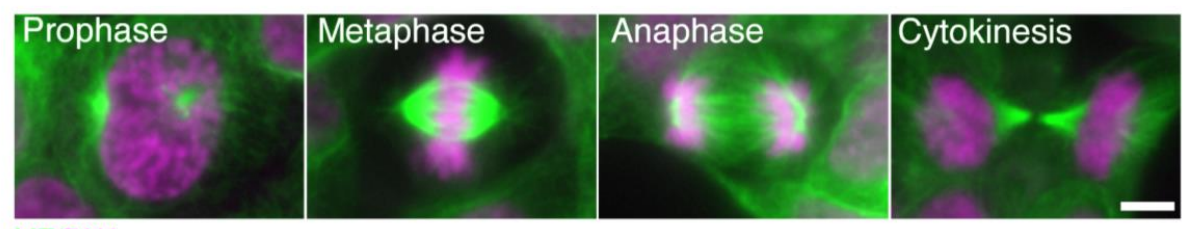

MT/DNA

\section{B Plant cell}

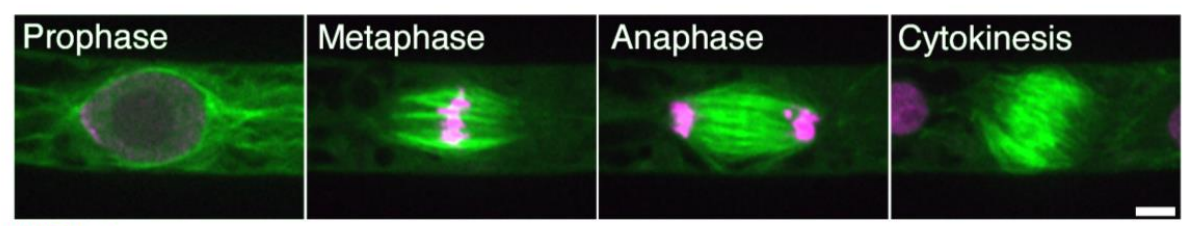

MT/Histone

C At nuclear envelope breakdown (prophase/prometaphase)

a

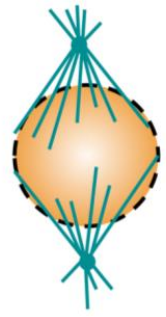

Liverwort

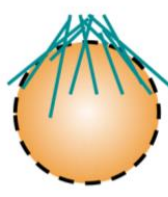

Moss

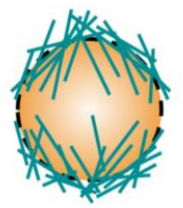

Seed plant

Figure 1. Animal and plant spindles. (A) Human HCT116 cells stained with anti- $\alpha$-tubulin antibody (green) and DAPI (purple); (B) Spindles in the moss Physcomitrella. patens highlighted by GFP-tubulin (green) and histone H2B-RFP (purple). The two main differences between animal and plant spindles are (1) the presence of centrosomes and well-developed astral MTs in animal spindles, and (2) the morphology of the anaphase spindle (the 'phragmoplast' in plants). Bars, $5 \mu \mathrm{m}$; (C) distinct types of MT formation at the beginning of prometaphase (at NEBD) in liverwort, moss, and angiosperm. (a) In liverwort, polar organisers (POs) are assembled and act as MTOCs (microtubule-organising centres). Unlike the centrosome, however, the PO is merged into the spindle and cannot be observed as a distinct structure in metaphase $[15,16]$. The genes required for PO formation are unknown; (b) In moss protonemata, MTs are asymmetrically accumulated around the nucleus and are more abundant on the apical side [17]. An RNAi study indicated that their formation depends on $\gamma$-tubulin, but not augmin; (c) In most angiosperm cell types, two loosely organised MT structures known as 'polar caps' are detected around the nucleus [18]. $\gamma$-Tubulin is localised at this region and MTs are actively generated [19]. 


\subsection{Mitotic Spindle Assembly in Seed Plants}

Researchers have elucidated the mechanism of acentrosomal spindle formation in land plants through microscopic observation and have revealed the processes common to, and different from, animal somatic cells $[20,21]$. One of the best-characterised cell types with regard to mitotic spindle assembly is the endosperm of African blood lily Haemanthus. In the absence of centrosomes, abundant MTs are detected around the nuclear envelope during prophase [22]. Immunofluorescence microscopy identified MT converging centres within the MT cloud, which was consistent with the idea that they are the major MT nucleation sites at this stage [23,24]. MTs around the nucleus are gradually organised into a spindle-like structure, called the 'prophase spindle' (or 'prospindle'). The prophase spindle has either a bipolar fusiform or multipolar structure [23]. After NEBD, MTs emanating from the converging centres associate with kinetochores to form kinetochore MTs [24]. MTs are also likely nucleated near the chromosome/kinetochore independent of prophase spindles during the prometaphase as an MT depolymerisation/regrowth assay detected chromosome-proximal MT formation [25]. Those MTs are then organised into an overall bipolar configuration. Electron microscopy showed that the majority of the MTs are oriented in such a way that plus ends are pointed to the chromosome/kinetochore, similar to animal spindles [26]. However, the metaphase spindle is barrel-shaped rather than fusiform, as the pole is not tightly focused at one point; multiple kinetochore and non-kinetochore MTs are converged or cross-linked locally and, thus, multiple mini-poles are observed [23]. Immunostaining of MTs also identified 'fir tree' structures within the spindle, in which many MTs branched off from kinetochore MTs [27]. With the start of anaphase, sister chromatids are separated and then segregated to the pole by kinetochore MT depolymerisation, analogous to animal spindles. During telophase, the phragmoplast forms and is followed by centrifugal expansion towards the cell cortex [28].

Arabidopsis thaliana is currently the most frequently used plant organism for genetic studies, and the mitotic spindle assembly process has been observed in several Arabidopsis tissues and suspension cells [19,29,30]. The tobacco BY-2 cell line is another popular system for mitosis imaging [31]. In these cells, MTs accumulate at the nuclear envelope and form prophase spindles (also called 'polar caps'), as occurs in Haemanthus endosperm. Upon NEBD, MTs emanating from polar caps become a source of spindle MTs. Thus, the initial spindle assembly process in prometaphase is similar to that observed in the Haemanthus endosperm. The processes of metaphase, anaphase, and telophase are also analogous to those described for the endosperm. Unlike the endosperm, however, most seed-plant tissues have the preprophase band (PPB) that is a structure consisting of parallel MT arrays beneath the cell cortex that appears prior to mitosis and marks the future division plate. The PPB ensures the bipolarity of prophase spindles. While this structure is critical for division plane determination and polar cap bipolarity [32], we will not discuss this structure further in this review as they generally disappear or degenerate during the prophase and are dispensable for bipolar metaphase spindle assembly per se (see $[33,34]$ as recent reviews on PPBs).

\subsection{Mitotic Spindle Assembly in Bryophytes}

Bryophytes have also been the subject of microscopic analysis of the mitotic spindle formation process. This process, particularly during the prophase, is somewhat different from that observed in seed plants (Figure 1C). In liverwort, prior to the appearance of prophase spindles, centrosome-like MT organising centres (MTOCs), called polar organisers (PO), appear in the cytoplasm $[35,36]$. The PO is similar to centrosomes in that they produce astral MTs. However, the PO is a transient structure that does not have centriole core, and during spindle formation, is no longer identified as a discrete structure. To the best of our knowledge, the roles of POs have not been experimentally demonstrated. It is, however, plausible that they function as an MT nucleation centre, as well as ensuring spindle bipolarity because they are stained well with antibodies against $\gamma$-tubulin, the major MT nucleator in eukaryotes $[37,38]$. In moss, conversely, PO-like structures have not been observed; instead, MTs are enriched around the nuclear envelope in prophase. These MTs emanating from the nuclear envelope represent the major source of prometaphase spindles, similar to Haemanthus $[15,17]$. In the hornwort, 
MTOCs are associated with plastids $[15,39]$. Despite the apparent differences in the earliest phase of spindle assembly, the morphology of the metaphase spindle of bryophytes is similar to that of Haemanthus endosperm, suggesting that a similar molecular factor is involved in the spindle assembly process during the prometaphase [15].

\section{Conservation of Spindle Assembly Factors}

The molecular factors in yeast and animal spindles have been extensively surveyed using genetics (including RNAi screening) and biochemistry (such as mass spectrometric protein identification). It is believed that most of the key factors have been identified [5,40-43]. However, since the experimental system is cumbersome and the genes are highly redundant, few genes required for spindle assembly in plants have been identified using these techniques. To characterise the putative molecular factors involved in plant spindle assembly, we performed an extensive database search (including BLAST sequence homology searching) on 131 known animal and yeast spindle factors (Table 1). As the targets, we selected Arabidopsis and the moss Physcomitrella patens, for which complete genome sequences are available [44,45], and molecular dissection of the spindle is arguably most advanced. For some genes, similar or more extensive homologue lists have previously been generated by other researchers (e.g., [46,47]); we double-checked the conservation/non-conservation of those genes with our procedure and included the references in the table.

In our search, homologues for most of the animal proteins were identified. All Arabidopsis genes are conserved in the moss P. patens; this suggests that they are likely to be found in a vast majority of land plant species. Nevertheless, our search failed to identify many components of three functional modules, namely, centrosomes, the cytoplasmic dynein complex, and kinetochores. 
Table 1. List of homologues of spindle assembly factors.

\begin{tabular}{|c|c|c|c|c|c|c|c|c|}
\hline & Generic Name & H. sapiens & D. melanogaster & S. pombe & P. patens & A. thaliana $\left({ }^{*}\right.$ identified with BLAST) & A. thaliana Gene Acession \# & References \\
\hline \multirow{11}{*}{$\begin{array}{c}\text { Kinase/ } \\
\text { phosphatase/ } \\
\text { signalling }\end{array}$} & Cdk1 & & & & & $*$ & AT3G48750 & \\
\hline & Aurora kinase & & & & & * & AT4G32830 etc. & [48] \\
\hline & Plk1 & & & & & & & [49] \\
\hline & Haspin & & & & & * & AT1G09450 & \\
\hline & Ran & & & & & $*$ & AT5G20010 etc. & \\
\hline & RCC1 & & & & & * & AT5G63860 etc. & \\
\hline & RanGAP & & & & & $*$ & AT3G63130, AT5G19320 & \\
\hline & PP2A & & & & & * & AT1G69960 etc. & [50] \\
\hline & Endosulfine & & & & & & AT1G69510 & [51] \\
\hline & PP1 & & & & & 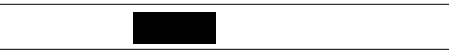 & AT2G29400 & [50] \\
\hline & PP6 & & & & & * & AT3G19980 & {$[50]$} \\
\hline \multirow{7}{*}{ Centriole } & Plk4 & & & & & & & [52] \\
\hline & Sas4 & & & & & & & {$[0<]$} \\
\hline & Sas5/Ana2/STIL & & & & & & & \\
\hline & Sas6 & & & & & ( & & [52] \\
\hline & Spd2/CEP192 & & & & & & & \\
\hline & Ana1/CEP295 & & & & & & & \\
\hline & Ana3/Rotatin & & & & & & & \\
\hline \multirow{8}{*}{ Motor/MAPs } & Kin4/chromokinesin & & & & & * & AT5G60930 etc. & \multirow{8}{*}[53,54]{} \\
\hline & Kin5 & & & & & $*$ & AT2G28620 etc. & \\
\hline & Kin6 & & & & & & & \\
\hline & Kin7/CENP-E & & & & & $*$ & AT3G10180 etc. & \\
\hline & Kin8 & & & & & * & AT1G18550, AT3G49650 & \\
\hline & Kin12/KIF15 & & & & & $*$ & AT3G19050 etc. & \\
\hline & Kin13 & & & & & * & AT3G16060, AT3G16630 & \\
\hline & Kin14 & & & & $\overline{7}$ & * & AT4G21270 etc. & \\
\hline
\end{tabular}


Table 1. Cont

\begin{tabular}{|c|c|c|c|c|c|c|c|c|}
\hline & Generic Name & H. sapiens & D. melanogaster & S. pombe & P. patens & A. thaliana (* identified with BLAST) & A. thaliana Gene Acession \# & References \\
\hline & DHC & & & & & & & \\
\hline & DIC & & & & & & & [55] \\
\hline & DLC (LC8) & & & & & $*$ & AT4G15930 etc. & \\
\hline & Dynactin p50 & & & & & & & \\
\hline & Dynactin p150 & & & & & & & \\
\hline & Dynactin ARP1 & & & & & & & {$[56]$} \\
\hline & PRC1/MAP65/Ase1 & & & & & * & AT3G60840 etc. & \\
\hline & Katanin (p60) & & & & & * & AT1G80350 & \\
\hline & HURP & & & & & & & \\
\hline & TACC & & & & & & & \\
\hline & TPX2 & & & & & * & AT1G03780 etc. & [57] \\
\hline \multirow{12}{*}{ Nucleation } & $\gamma$-Tubulin & & & & & * & AT3G61650, AT5G05620 & {$[58]$} \\
\hline & GCP2/3 & & & & & * & AT5G17410, AT5G06680 & {$[46]$} \\
\hline & $\mathrm{GCP} 4 / 5 / 6$ & & & & & * & At3g53760 etc. & {$[46,59]$} \\
\hline & NEDD1 & & & & & $*$ & AT5G05970 & [60] \\
\hline & Mzt1 & & & & & * & AT1G73790, AT4G09550 & [61-63] \\
\hline & Mzt2 & & & & & & & {$[64]$} \\
\hline & Augmin (8 subunits) & & & & & $*$ & At5g 40740 etc. & {$[17,46,65]$} \\
\hline & Pericentrin/D-plp & & & & & & & [64] \\
\hline & AKAP9 & & & & & & & {$[64,66]$} \\
\hline & SPC110/Pcp1 & & & & & & & \multirow{3}{*}[64]{} \\
\hline & CDK5RAP2/Cnn & & & & & & & \\
\hline & Myomegalin & & & & & & & \\
\hline \multirow{7}{*}{$\begin{array}{l}\text { Microtubule } \\
\text { plus end }\end{array}$} & ch-TOG/XMAP215 & & & & & $*$ & AT2G35630 & [67] \\
\hline & EB1 & & & & & $*$ & AT5G62500 etc. & \\
\hline & SLAIN/Sentin & & & & & & & \\
\hline & CLIP170 & & & & & & & \\
\hline & CLASP & & & & & $*$ & AT2G20190 & \\
\hline & SKAP & & & & & & & \\
\hline & Astrin & & & & & & & \\
\hline
\end{tabular}


Table 1. Cont

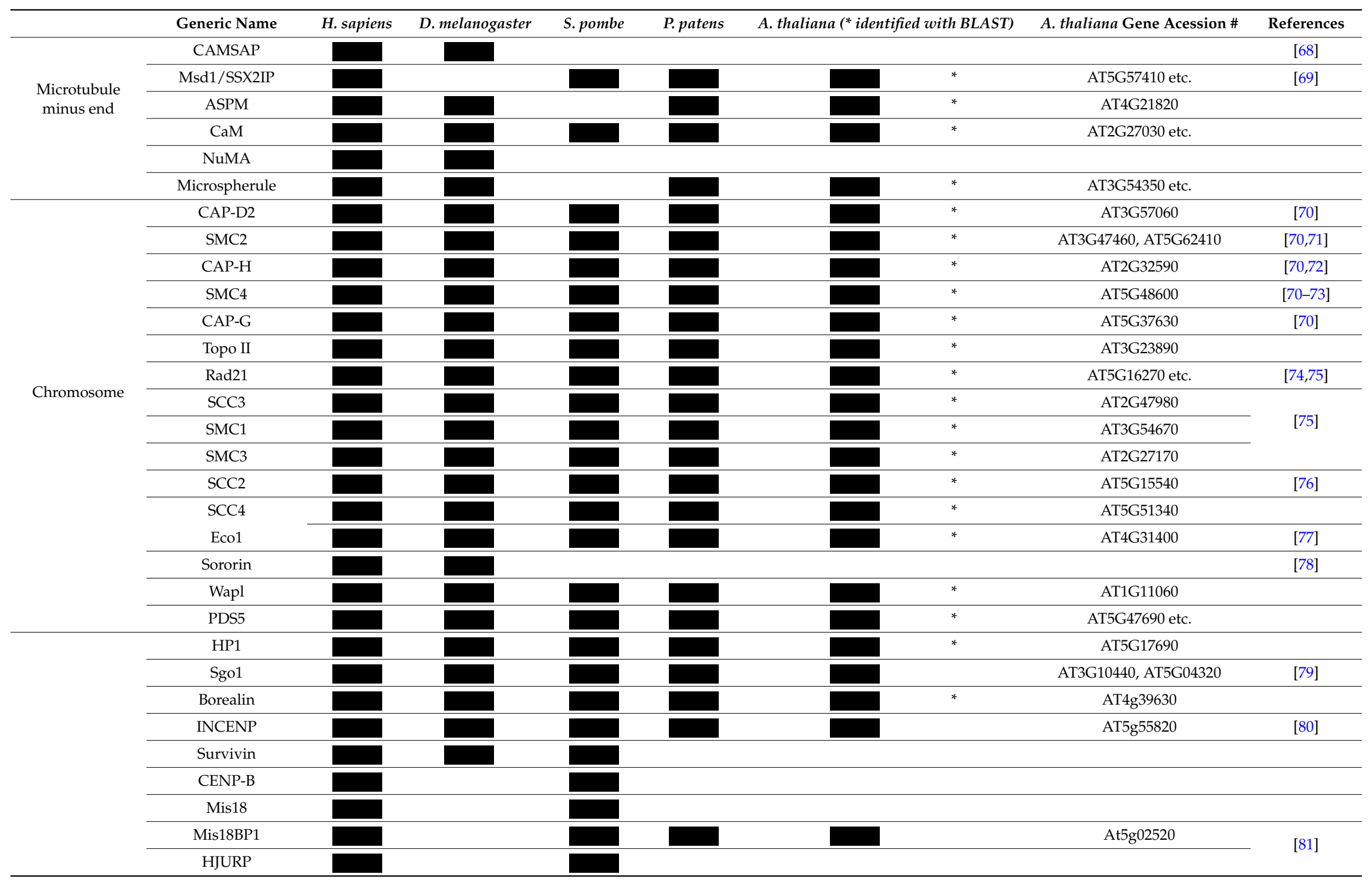


Table 1. Cont

\begin{tabular}{|c|c|c|c|c|c|c|c|c|}
\hline & Generic Name & H. sapiens & D. melanogaster & S. pombe & P. patens & A. thaliana $\left({ }^{*}\right.$ identified with BLAST) & A. thaliana Gene Acession \# & References \\
\hline \multirow{32}{*}{$\begin{array}{l}\text { Kinetochore/ } \\
\text { centromere }\end{array}$} & Cal1 & & & & & & & \\
\hline & CENP-A & & & & & $*$ & AT1G01370 & [82] \\
\hline & CENP-C & & & & & $*$ & AT1G15660 & [83] \\
\hline & CENP-S & & & & & * & AT5G50930 & [84] \\
\hline & CENP-X & & & & & & AT1G78790 & [85] \\
\hline & CENP-T & & & & & & & \\
\hline & CENP-W & & & & & & & \\
\hline & CENP-L & & & & & & & \\
\hline & CENP-N & & & & & & & \\
\hline & CENP-H & & & & & & & \\
\hline & CENP-I & & & & & & & \\
\hline & CENP-K & & & & & & & \\
\hline & CENP-M & & & & & & & \\
\hline & CENP-O & & & & & * & AT5G10710 & \\
\hline & CENP-P & & & & & & & \\
\hline & CENP-Q & & & & & & & \\
\hline & CENP-U & & & & & & & \\
\hline & CENP-R & & & & & & & \\
\hline & Mis12 & & & & & . & AT5G35520 & [86] \\
\hline & Dsn1/Mis13 & & & & & & AT3G27520 & \\
\hline & Nnf1 & & & & & & AT4G19350 & \\
\hline & Ns11/Mis14 & & & & & & & \\
\hline & KNL1 & & & & & & AT2G04235 & [87] \\
\hline & Ndc80 & & & & & $*$ & AT3G54630 & \\
\hline & Nuf2 & & & & & $*$ & AT1G61000 & \\
\hline & Spc24 & & & & & ( & AT3G08880, AT5G01570 & \\
\hline & Spc25 & & & & & $*$ & AT3G48210 & \\
\hline & Ska1 & & & & & $*$ & AT3G60660 & \\
\hline & Ska2 & & & & & 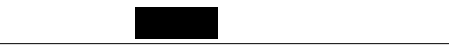 & AT2G24970 & \\
\hline & Ska3 & & & & & & AT5G06590 & \\
\hline & Dam1 & & & & & & & \\
\hline & CENP-F & & & & & & & \\
\hline
\end{tabular}


Table 1. Cont.

\begin{tabular}{|c|c|c|c|c|c|c|c|c|}
\hline & Generic Name & H. sapiens & D. melanogaster & S. pombe & P. patens & A. thaliana $\left({ }^{*}\right.$ identified with BLAST) & A. thaliana Gene Acession \# & References \\
\hline \multirow{12}{*}{$\begin{array}{c}\text { Spindle } \\
\text { assembly } \\
\text { checkpoint (SAC) }\end{array}$} & Mad1 & & & E & & * & AT5G49880 & \\
\hline & Mad2 & & & & & * & AT3G25980 & [88] \\
\hline & Mad3 / BubR1 & & & & & * & AT2G33560, AT5G05510 & {$[88,89]$} \\
\hline & Bub1 & & & & & * & AT2G20635 & \\
\hline & Bub3 & & & & & * & AT3G19590, AT1G49910 & \\
\hline & Mps1 & & & & & * & AT1G77720 & [90] \\
\hline & Tpr & & & & & * & AT1G79280 & [91] \\
\hline & Cdc20 & & & & & * & AT4G33270 etc. & \\
\hline & Spindly & & & & & & & \\
\hline & Rod & & & & & & & \\
\hline & Zwilch & & & & & & & \\
\hline & Zw10 & & & & & * & AT2G32900 & [92] \\
\hline
\end{tabular}

Black boxes indicate that homologous genes are present. Boxes are left blank if no clear homologues are present. The Arabidopsis genes identified with the BLAST search are marked with asterisks $\left(^{*}\right)$. Gene accession numbers for Arabidopsis genes were presented; however, just one or two numbers were provided when more homologues were identified or for protein complexes (augmin and GCPs). The identities of other subunits are found in the references presented in a separate column.

The homologous genes were sought as follows:

1. Animal and yeast genes required for spindle assembly were found in the literature $[40,52,64,93]$;

2. The amino acid sequences of the Homo sapiens proteins were retrieved from the NCBI database. When multiple isoforms were identified, only one randomly selected isoform was used;

3. Drosophila melanogaster (fruit fly) and Schizosaccharomyces. pombe (fission yeast) homologues were sought in the NCBI 'Homologene' or 'Gene' search. When clear homologues were not identified, the BLAST search was performed;

4. Homologous genes of Arabidopsis thaliana and Physcomitrella. patens were sought using BLAST (query: human or yeast protein);

5. If no clear homologues could be identified, the databases for individual species were searched (PomBase, fly base, PHYSCObase, or TAIR). For the query, human (or, in some instances, fly) gene names or keywords (e.g., 'centromere', 'kinetochore', or 'CENP') were used;

6. If homologous genes were still not identified, the name was searched using Google Scholar and PubMed;

7. The sequences of plant Dsn1/Nnf1/Spc24/Ska3 and Msd1 were provided by Dr. Geert Kops (Utrecht University, The Netherlands) and Dr. Takashi Hashimoto (Nara Institute of Science and Technology, Japan), respectively. 


\subsection{Centrosome Proteins}

As expected, animal centriole proteins, such as the cartwheel component Sas6, are mostly missing from the Arabidopsis genome. In contrast, pericentriolar proteins, like the subunits of the $\gamma$-tubulin ring complex ( $\gamma$-TuRC) are more conserved. This makes sense because $\gamma$-TuRC functions at other places besides the centrosome, including the spindle MTs $[15,17,58,94,95]$. However, the regulators of $\gamma$-TuRC at the animal centrosome, such as the localisation factor/activator CDK5RAP2/Cnn, Plk1 kinase (polo-like kinase), and pericentrin, are largely unidentified in plants. In animals and yeasts, $\gamma$-TuRC alone lacks potent MT nucleating activity. Plants, therefore, might possess some plant-specific $\gamma$-TuRC activation factors. However, since centrosomal components are often difficult to identify by BLAST because of low sequence identity, their homologues may be present in the genome but have not yet been identified [96]. Several centriole components are found in the moss genome; these genes are likely to be required for the formation of the basal body that is used for flagella assembly in sperm [97].

\subsection{Dynein Complex and Its Localisation Factors}

Cytoplasmic dynein forms a large complex with several associated subunits and is a major MT-based motor protein in animals and fungi [98]. It moves towards the minus-end of MTs, delivers various cargoes, and generates force on the MT. In mitosis, cargoes include mitotic checkpoint proteins, chromosomes, and free cytoplasmic MTs. As previously shown [99], almost the entire dynein complex is absent from the Arabidopsis genome (except for the LC8 subunit that binds to other proteins such as myosin [100]). Furthermore, dynein adaptor proteins at the kinetochore or cell cortex, such as Rod, Zwilch, Spindly, or NuMA, are also missing. Thus, almost the entire dynein functional module has been lost in Arabidopsis. Since dynein plays various important roles in animals, plants must have developed an alternative force-generating system. One candidate is kinesin-14, which, like dynein, has minus-end-directed motility [101-103] and plays a partially redundant role in spindle pole organisation in animal cells $[9,104]$. Moss does not have cytoplasmic dynein but has axonemal dynein that is likely used for sperm motility [105]. Several dynein accessory subunits found in moss may be associated with the axonemal dynein heavy chain.

\subsection{Kinetochore Components}

Factors required for high-ordered chromosome organisation, such as condensin and cohesin complexes, and core components of the mitotic checkpoint [106] are highly conserved. However, many components of the kinetochore (the MT attachment site during mitosis) could not be identified. They might be present but could not be identified via BLAST, as kinetochore protein sequences are, in general, highly divergent among species, even within the metazoans (e.g., Drosophila melanogaster and humans) [107]. Current biochemical research has elucidated kinetochore subcomplexes [93]. We have identified at least one component per subcomplex in plants, with the exception of the CENP-H/I/K/M subcomplex. This suggests that other components with low sequence similarity are also present. It is also possible, however, that plants have either lost certain subunits or acquired plant-specific components. The former case is seen in Drosophila, in which most of the CENP components were lost during evolution. Systematic studies, such as those involving proteomics, are necessary to identify the complete set of kinetochore components in plants.

\section{Molecular Mechanisms of Spindle Assembly in Land Plants}

In this section, we draw a current molecular model showing how spindles and phragmoplasts are assembled in plant cells (Figure 2). The diagram described here is based on experimental results obtained using reliable methodology such as mutant or RNAi analysis. The knowledge was derived mainly from P. patens, which is a system that allows rapid loss-of-function analysis and high-resolution time-lapse microscopy [108], and Arabidopsis, which has a rich history of mutant collection [29]. However, since genes are well conserved across land plant species, the basic mechanism could 
be conserved in other plant cell types. We do not include information obtained solely for animal orthologues; however, it is possible that the uncharacterised plant homologues of animal spindle proteins have identical molecular activities and functions.

\section{A. Metaphase}

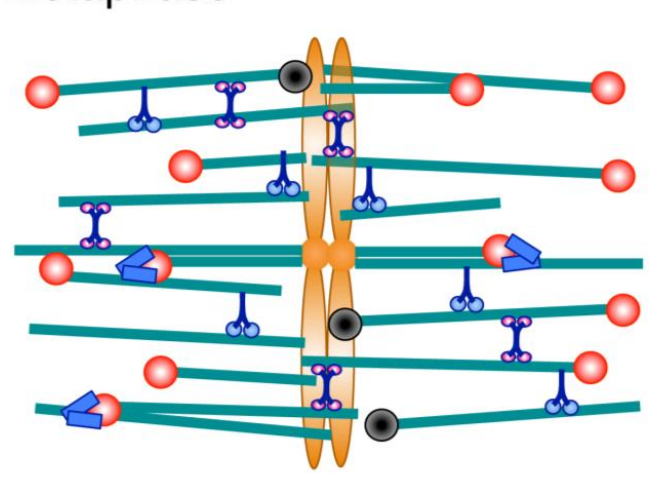

B. Telophase

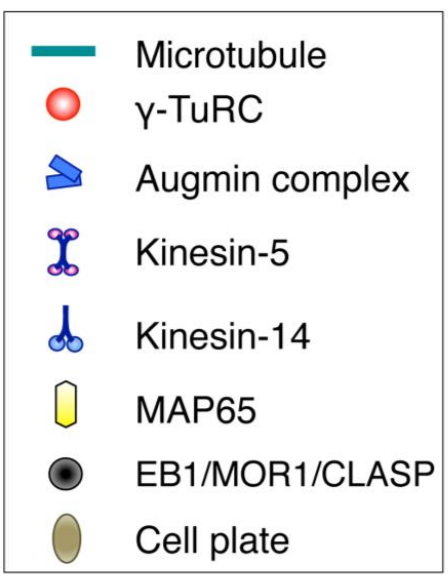

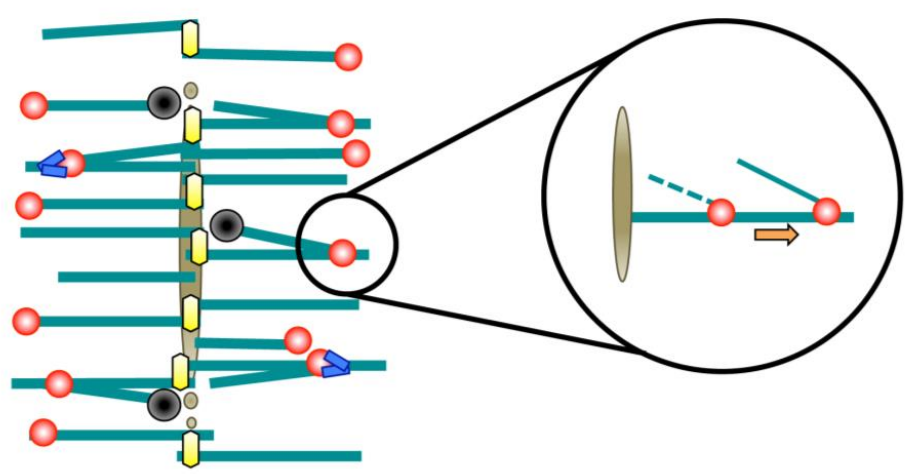

Figure 2. Molecular factors for spindle/phragmoplast assembly. (A) During prometaphase and metaphase, MTs are nucleated mainly by the $\gamma$-tubulin ring complex ( $\gamma$-TuRC) and its recruitment/activation factor, the augmin complex. Multiple cross-linking proteins, including kinesin-5 and kinesin-14, shape the spindle. Spindle length is regulated by conserved MT plus-end-regulating proteins (EB1/MOR1/CLASP); (B) The MT-based arrays assembled after sister chromatid separation are called phragmoplasts. The central factors for MT generation in the phragmoplast are $\gamma$-TuRC and augmin, whereas MAP65 is an essential MT cross-linker that ensures phragmoplast bipolarity. MT plus ends are regulated by the same set of proteins as those acting during metaphase. Newly nucleated MTs are transported poleward via an unknown molecular mechanism.

\subsection{Spindle Assembly}

Genetic analyses of $\gamma$-tubulin and their associated subunits have clarified the pivotal role of the $\gamma$-TuRC in spindle MT generation $[59,60,109,110]$. Recently, a mechanism underlying $\gamma$-TuRC activation was also uncovered. Studies on moss and Arabidopsis indicated that the eight-subunit complex augmin is a key factor in increasing spindle MTs during prometaphase via $\gamma$-TuRC localisation and activation [17,65] (Figure 2A). Augmin was originally identified in Drosophila cells as a protein complex that drives MT-dependent MT generation by recruiting $\gamma$-tubulin onto existing spindle MTs [111]. In moss, RNAi knockdown of augmin subunits reduced MTs to $~ 50 \%$, suggesting that at least half of the spindle MTs were generated via augmin-dependent, branching nucleation during prometaphase [17]. Since RNAi knockdown left behind residual augmin proteins, it is likely that $50 \%$ is an underestimate. The fir-tree structure observed in Haemanthus endosperm spindles might represent augmin-dependent MTs [27]. Prior to the discovery of augmin, MT-dependent MT generation was 
described in detail for the cortical MT arrays in tobacco and Arabidopsis cells [95]. Recent studies in Arabidopsis demonstrated that this branching nucleation is an augmin-dependent process [112]. In contrast, the origin of augmin-independent spindle MTs after augmin RNAi is unknown. It is possible that, analogous to animal cells [8], prophase MTs, and chromatin-mediated nucleation in the prometaphase (which depends on RanGTP or aurora kinase) play a role in producing these MTs.

The molecular mechanism by which plant cells achieve bipolar arrangement without centrosomes is not well understood. In animals, the key molecules in the bipolar arrangement are kinesin- 5 and kinesin-12, which cross-link and slide apart anti-parallel MT overlaps in the spindle midzone [5]. This model may apply to certain plant tissues since an Arabidopsis mutant of kinesin-5 exhibits monopolar spindle formation in roots [113]. However, in moss protonemata, RNAi knockdown of kinesin-5 did not show monopolarisation. Moreover, GFP-tagged kinesin-5 is scarcely detected at the midzone [114]. Genes encoding kinesin-12 are amplified in plants. Therefore, it is possible that this motor redundantly plays a major role in bipolarity establishment and maintenance in some plant cell types. A comprehensive functional analysis of the kinesin-12 subfamily is required to test this hypothesis.

In animals, spindle coalescence is mediated by the partially redundant functions of kinesin-14 and cytoplasmic dynein $[9,104]$. Kinesin-14 has a second MT binding site in its tail domain and works as an MT cross-linker. In plants, two closely related kinesin-14 proteins, ATK1 and ATK5, have been shown to play a similar role [30,115-117]. When ATK5 was absent in root cells, spindles were less focused than they were in control cells [30]. However, whether the MT converging centres observed at the pole [23] are solely organised by the kinesin-14 motor remains unclear; in fly cells, this local crosslinking was dependent on an additional factor, ASPM/Asp [11,118], which is conserved, but uncharacterised, in plants.

Spindle length appears to be controlled by MT dynamics at plus ends, similar to animal cells. XMAP215/Dis1 family protein is an established MT polymerase, and the mor1 (XMAP215/Dis1 orthologue) mutant has shorter spindles in Arabidopsis [67,119]. EB1 is also a critical regulator of MT plus ends, with shorter spindle formation reported for the Arabidopsis eb1c mutant [120]. The cytoplasmic linker-associated protein (CLASP) is an essential factor for MT polymerisation at the kinetochore in animals [121], and mutations in this gene in Arabidopsis resulted in significantly shorter spindles [122]. In the animal spindle, CLASP-dependent MT polymerisation and motor-dependent, poleward MT transport/sliding are coupled with minus end depolymerisation by the kinesin-13 depolymerase to maintain spindle length at the steady state ('MT flux'; [123]). MT flux has been observed in plant spindles, suggesting that MT minus ends are also regulated by a depolymerising factor [124].

\subsection{Phragmoplast Assembly}

The phragmoplast begins to assemble upon sister chromatid separation (Figure 2B). The overall structural similarity, namely, bipolar MT array with anti-parallel MT interdigitation in the middle, have raised the notion that the phragmoplast is analogous to the central spindle or midbody in animal cells [125]. Recently reported data on MT generation further support this idea. In both structures, some MTs are constantly generated de novo in an augmin- and $\gamma$-tubulin-dependent manner $[13,17]$. When augmin is depleted in moss, MTs are diminished and phragmoplasts eventually disappear before they reach the cell cortex. A plausible explanation for this phenotype is that augmin utilises existing MTs, such as those carried over from metaphase, as templates for new MT nucleation. About $50 \%$ of the MTs in the central spindle of animal cells are generated in an augmin-dependent manner [13]. However, animal cells seem to have additional MT generation pathways during anaphase: at that time, hepatoma up-regulated proteins (HURP) are involved in chromosome-proximal MT generation [13]. HURP-like proteins have not been identified in the plant genome.

The key factor that maintains phragmoplast bipolarity is MAP65 (PRC1/Ase1 orthologue). This is an anti-parallel MT cross-linking protein whose activity is conserved in both yeasts and animals [126]. 
When three paralogous MAP65 genes are simultaneously knocked down in moss, MT bipolarity is lost and cytokinesis fails [127]. In Arabidopsis, bipolarity is maintained in known MAP65 mutants [128,129] but it is possible that multiple MAP65s work redundantly, and cross-linking activity persists in the mutant [130]. Other proteins, such as kinesins, might also constitute a redundant cross-linking mechanism [131].

The signalling pathway underlying phragmoplast MT regulation differs between animals and plants. In animals, the key kinases required for proper central spindle assembly are Plk1 and Aurora-B. They are concentrated at the midzone and phosphorylate multiple MT-regulating proteins including the MAP65 orthologue PRC1 [132,133]. In contrast, plants do not have Plk1. The aurora kinase constitutes a signalling pathway during cytokinesis, but the mutant exhibits a defect in orientation, but not assembly per se of the phragmoplast [134]. In plants, the MAP kinase cascade also constitutes the late mitotic signalling pathway (called the NACK-PQR pathway) [135]. One of the downstream factors in plants is also MAP65. The phosphorylation of MAP65 down-regulates its MT-bundling activity which, in turn, stimulates the progression of cytokinesis [136]. Thus, in plants, the development of MAPK signalling might have compensated for the loss of Plk1 kinase.

The phragmoplast length is regulated by MT-associated proteins; similar to metaphase spindles, shorter phragmoplasts are observed in the mutants of MOR1, EB1, and CLASP [119,120,122]. In addition, katanin-mediated severing may affect MT length in some cell types [137]. MT flux is also observed within the phragmoplast, but the molecules responsible remain to be identified [138].

\section{Conclusions and Future Perspectives on Spindle Research in Plants}

At first glance, plant and animal spindles look quite different. However, the database search suggests that only a few of the mitotic elements present in animals are missing from the plant genome. Our queries using animals could not elucidate the genes that evolved uniquely in plants. Therefore, it is possible that some plant-specific genes for spindle assembly have yet to be identified. Nevertheless, most of the gene repertoire is probably common to both animals and plants.

However, the mechanism of plant spindle assembly is formally not yet well understood. First, although gene conservation predicts that homologous proteins possess similar biochemical activity, are found in similar locations, and execute similar functions, each of these must be tested experimentally. Indeed, recent 'repeat' experiments using the plant orthologues of well-characterised animal genes have revealed unexpected functions, such as the role of kinesin-5 in chromosome alignment or cytokinesis [114] and a $\gamma$-TuRC-interacting protein in centromere integrity [61]. Regarding localisation dynamics, a comprehensive study in moss showed that 42 out of 43 mitotic kinesins were localised at a site not observed in animal studies [114]. Until recently, 'repeat' experiments intended to confirm animal study results were very time-consuming due to the lack of a model cell system for rapid investigation. The recent development of quick and robust loss-of-function tools such as conditional RNAi and CRISPR/Cas9-based genome editing technology in moss and liverwort, as well as advances in live microscopy, have provided an opportunity to delve into putative spindle assembly factors in plants [17,139-142].

Second, it is not yet known how plants compensate for the lack of two major components, centrosomes and dynein. In animal and yeast, these two components are critical for spindle positioning, which is a crucial process in determining the cell division axis and symmetry/asymmetry [143]. It has been shown that genetic perturbation of the PPB causes division axis abnormalities in seed plants $[33,34]$. Yet little is known about the molecular mechanism underlying the PPB-dependent determination of the spindle axis. It is remarkable that plants evolved a unique PPB-based mechanism to substitute for centrosome function [144]. The mechanism by which plant spindles are oriented in the proper direction remains a fascinating, and as yet unanswered, question.

Acknowledgments: We thank Geert Kops (Utrecht University, The Netherlands) and Takashi Hashimoto (Nara Institute of Science and Technology, Japan) for providing information about some putative plant spindle/chromosome proteins and Ami Ito (Nagoya University) for furnishing human spindle images. The plant 
research conducted in our laboratory is supported by the TORAY Science Foundation and by JSPS KAKNHI (15K14540 and 15H01227). Moé Yamada is a recipient of the JSPS pre-doctoral fellowship.

Conflicts of Interest: The authors declare no conflict of interest.

\section{References}

1. Inoue, S.; Sato, H. Cell motility by labile association of molecules. The nature of mitotic spindle fibers and their role in chromosome movement. J. Gen. Physiol. 1967, 50, S259-S292. [CrossRef]

2. Karp, G. Cell and Molecular Biology: Concepts and Experiments, 6th ed.; John Wiley: Hoboken, NJ, USA, 2010.

3. Conduit, P.T.; Richens, J.H.; Wainman, A.; Holder, J.; Vicente, C.C.; Pratt, M.B.; Dix, C.I.; Novak, Z.A.; Dobbie, I.M.; Schermelleh, L.; et al. A molecular mechanism of mitotic centrosome assembly in drosophila. eLife 2014, 3, e03399. [CrossRef] [PubMed]

4. Duncan, T.; Wakefield, J.G. 50 ways to build a spindle: The complexity of microtubule generation during mitosis. Chromosome Res. 2011, 19, 321-333. [CrossRef] [PubMed]

5. Reber, S.; Hyman, A.A. Emergent properties of the metaphase spindle. Cold Spring Harb. Perspect. Biol. 2015, 7, a015784. [CrossRef] [PubMed]

6. Walczak, C.E.; Heald, R. Mechanisms of mitotic spindle assembly and function. Int. Rew. Cytol. 2008, 265, 111-158.

7. Goshima, G.; Kimura, A. New look inside the spindle: Microtubule-Dependent microtubule generation within the spindle. Curr. Opin. Cell Biol. 2010, 22, 44-49. [CrossRef] [PubMed]

8. Hayward, D.; Metz, J.; Pellacani, C.; Wakefield, J.G. Synergy between multiple microtubule-generating pathways confers robustness to centrosome-driven mitotic spindle formation. Dev. Cell 2014, 28, 81-93. [CrossRef] [PubMed]

9. Walczak, C.E.; Vernos, I.; Mitchison, T.J.; Karsenti, E.; Heald, R. A model for the proposed roles of different microtubule-based motor proteins in establishing spindle bipolarity. Curr. Biol. 1998, 8, 903-913. [CrossRef]

10. Hatsumi, M.; Endow, S.A. Mutants of the microtubule motor protein, nonclaret disjunctional, affect spindle structure and chromosome movement in meiosis and mitosis. J. Cell Sci. 1992, 101, 547-559. [PubMed]

11. Wakefield, J.G.; Bonaccorsi, S.; Gatti, M. The drosophila protein asp is involved in microtubule organization during spindle formation and cytokinesis. J. Cell Biol. 2001, 153, 637-648. [CrossRef] [PubMed]

12. Goshima, G.; Scholey, J.M. Control of mitotic spindle length. Annu. Rev. Cell Dev. Biol. 2010, $26,21-57$. [CrossRef] [PubMed]

13. Uehara, R.; Goshima, G. Functional central spindle assembly requires de novo microtubule generation in the interchromosomal region during anaphase. J. Cell Biol. 2010, 191, 259-267. [CrossRef] [PubMed]

14. Glotzer, M. The 3ms of central spindle assembly: Microtubules, motors and maps. Nat. Rev. Mol. Cell Biol. 2009, 10, 9-20. [CrossRef] [PubMed]

15. Brown, R.C.; Lemmon, B.E. Dividing without centrioles: Innovative plant microtubule organizing centres organize mitotic spindles in bryophytes, the earliest extant lineages of land plants. AoB Plants 2011, 2011. [CrossRef] [PubMed]

16. Buschmann, H.; Holtmannspotter, M.; Borchers, A.; O’Donoghue, M.T.; Zachgo, S. Microtubule dynamics of the centrosome-like polar organizers from the basal land plant marchantia polymorpha. New Phytol. 2016, 209, 999-1013. [CrossRef] [PubMed]

17. Nakaoka, Y.; Miki, T.; Fujioka, R.; Uehara, R.; Tomioka, A.; Obuse, C.; Kubo, M.; Hiwatashi, Y.; Goshima, G. An inducible rna interference system in physcomitrella patens reveals a dominant role of augmin in phragmoplast microtubule generation. Plant Cell 2012, 24, 1478-1493. [CrossRef] [PubMed]

18. Lloyd, C.; Chan, J. Not so divided: The common basis of plant and animal cell division. Nat. Rev. Mol. Cell Biol. 2006, 7, 147-152. [CrossRef] [PubMed]

19. Chan, J.; Calder, G.; Fox, S.; Lloyd, C. Localization of the microtubule end binding protein eb1 reveals alternative pathways of spindle development in arabidopsis suspension cells. Plant Cell 2005, 17, 1737-1748. [CrossRef] [PubMed]

20. Baskin, T.I.; Cande, W.Z. The structure and function of the mitotic spindle in flowering plants. Ann. Rev. Plant Physiol. Plant Mol. Biol. 1990, 41, 277-315. [CrossRef]

21. Smirnova, E.A.; Bajer, A.S. Spindle poles in higher plant mitosis. Cell Motil Cytoskelet. 1992, 23, 1-7. [CrossRef] [PubMed] 
22. De Mey, J.; Lambert, A.M.; Bajer, A.S.; Moeremans, M.; De Brabander, M. Visualization of microtubules in interphase and mitotic plant cells of haemanthus endosperm with the immuno-gold staining method. Proc. Natl. Acad. Sci. USA 1982, 79, 1898-1902. [CrossRef] [PubMed]

23. Smirnova, E.A.; Bajer, A.S. Microtubule converging centers and reorganization of the interphase cytoskeleton and the mitotic spindle in higher plant haemanthus. Cell Motil Cytoskelet. 1994, 27, 219-233. [CrossRef] [PubMed]

24. Smirnova, E.A.; Bajer, A.S. Early stages of spindle formation and independence of chromosome and microtubule cycles in haemanthus endosperm. Cell Motil Cytoskelet. 1998, 40, 22-37. [CrossRef]

25. Falconer, M.M.; Donaldson, G.; Seagull, R.W. Mtocs in higher-plant cells-An immunofluorescent study of microtubule assembly sites following depolymerization by apm. Protoplasma 1988, 144, 46-55. [CrossRef]

26. Euteneuer, U.; Jackson, W.T.; McIntosh, J.R. Polarity of spindle microtubules in haemanthus endosperm. J. Cell Biol. 1982, 94, 644-653. [CrossRef] [PubMed]

27. Bajer, A.S.; Mole-Bajer, J. Reorganization of microtubules in endosperm cells and cell fragments of the higher plant haemanthus in vivo. J. Cell Biol. 1986, 102, 263-281. [CrossRef] [PubMed]

28. Lambert, A.M.; Bajer, A.S. Dynamics of spindle fibers and microtubules during anaphase and phragmoplast formation. Chromosoma 1972, 39, 101-144. [CrossRef]

29. Liu, B.; Ho, C.M.; Lee, Y.R. Microtubule reorganization during mitosis and cytokinesis: Lessons learned from developing microgametophytes in arabidopsis thaliana. Front. Plant Sci. 2011. [CrossRef] [PubMed]

30. Ambrose, J.C.; Cyr, R. The kinesin atk5 functions in early spindle assembly in arabidopsis. Plant Cell. 2007, 19, 226-236. [CrossRef] [PubMed]

31. Hayashi, T.; Sano, T.; Kutsuna, N.; Kumagai-Sano, F.; Hasezawa, S. Contribution of anaphase b to chromosome separation in higher plant cells estimated by image processing. Plant Cell Physiol. 2007, 48, 1509-1513. [CrossRef] [PubMed]

32. Ambrose, J.C.; Cyr, R. Mitotic spindle organization by the preprophase band. Mol. Plant 2008, 1, 950-960. [CrossRef] [PubMed]

33. Muller, S.; Wright, A.J.; Smith, L.G. Division plane control in plants: New players in the band. Trends Cell Biol. 2009, 19, 180-188. [CrossRef] [PubMed]

34. Rasmussen, C.G.; Humphries, J.A.; Smith, L.G. Determination of symmetric and asymmetric division planes in plant cells. Annu. Rev. Plant Biol. 2011, 62, 387-409. [CrossRef] [PubMed]

35. Fowke, L.C.; Pickett-Heaps, J.D. Electron microscope study of vegetative cell division in two species of marchantia. Can. J. Bot. 1978, 56, 467-475. [CrossRef]

36. Brown, R.C.; Lemmon, B.E. Polar organizers mark division axis prior to preprophase band formation in mitosis of the hepaticreboulia hemisphaerica (bryophyta). Protoplasma 1990, 156, 74-81. [CrossRef]

37. Shimamura, M.; Brown, R.C.; Lemmon, B.E.; Akashi, T.; Mizuno, K.; Nishihara, N.; Tomizawa, K.; Yoshimoto, K.; Deguchi, H.; Hosoya, H.; et al. Gamma-Tubulin in basal land plants: Characterization, localization, and implication in the evolution of acentriolar microtubule organizing centers. Plant Cell 2004, 16, 45-59. [CrossRef] [PubMed]

38. Brown, R.C.; Lemmon, B.E.; Horio, T. Gamma-Tubulin localization changes from discrete polar organizers to anastral spindles and phragmoplasts in mitosis of marchantia polymorpha 1. Protoplasma 2004, 224, 187-193. [CrossRef] [PubMed]

39. Brown, R.C.; Lemmon, B.E. Preprophase microtubule systems and development of the mitotic spindle in hornworts (bryophyta). Protoplasma 1988, 143, 11-21. [CrossRef]

40. Goshima, G.; Wollman, R.; Goodwin, N.; Zhang, J.M.; Scholey, J.M.; Vale, R.D.; Stuurman, N. Genes required for mitotic spindle assembly in drosophila s2 cells. Science 2007, 316, 417-421. [CrossRef] [PubMed]

41. Sonnichsen, B.; Koski, L.B.; Walsh, A.; Marschall, P.; Neumann, B.; Brehm, M.; Alleaume, A.M.; Artelt, J.; Bettencourt, P.; Cassin, E.; et al. Full-Genome rnai profiling of early embryogenesis in caenorhabditis elegans. Nature 2005, 434, 462-469. [CrossRef] [PubMed]

42. Hutchins, J.R.; Toyoda, Y.; Hegemann, B.; Poser, I.; Heriche, J.K.; Sykora, M.M.; Augsburg, M.; Hudecz, O.; Buschhorn, B.A.; Bulkescher, J.; et al. Systematic analysis of human protein complexes identifies chromosome segregation proteins. Science 2010, 328, 593-599. [CrossRef] [PubMed]

43. Hoyt, M.A.; Geiser, J.R. Genetic analysis of the mitotic spindle. Annu. Rev. Genet. 1996, 30, 7-33. [CrossRef] [PubMed] 
44. Rensing, S.A.; Lang, D.; Zimmer, A.D.; Terry, A.; Salamov, A.; Shapiro, H.; Nishiyama, T.; Perroud, P.F.; Lindquist, E.A.; Kamisugi, Y.; et al. The physcomitrella genome reveals evolutionary insights into the conquest of land by plants. Science 2008, 319, 64-69. [CrossRef] [PubMed]

45. Arabidopsis Genome, I. Analysis of the genome sequence of the flowering plant arabidopsis thaliana. Nature 2000, 408, 796-815. [CrossRef] [PubMed]

46. Hamada, T. Microtubule organization and microtubule-associated proteins in plant cells. Int. Rev. Cell Mol. Biol. 2014, 312, 1-52. [PubMed]

47. Gardiner, J. The evolution and diversification of plant microtubule-associated proteins. Plant J. 2013, 75, 219-229. [CrossRef] [PubMed]

48. Demidov, D.; Van Damme, D.; Geelen, D.; Blattner, F.R.; Houben, A. Identification and dynamics of two classes of aurora-like kinases in arabidopsis and other plants. Plant Cell 2005, 17, 836-848. [CrossRef] [PubMed]

49. De Carcer, G.; Manning, G.; Malumbres, M. From plk1 to plk5: Functional evolution of polo-like kinases. Cell Cycle 2011, 10, 2255-2262. [CrossRef] [PubMed]

50. Moorhead, G.B.; De Wever, V.; Templeton, G.; Kerk, D. Evolution of protein phosphatases in plants and animals. Biochem. J. 2009, 417, 401-409. [CrossRef] [PubMed]

51. Labandera, A.M.; Vahab, A.R.; Chaudhuri, S.; Kerk, D.; Moorhead, G.B. The mitotic pp2a regulator ensa/arpp-19 is remarkably conserved across plants and most eukaryotes. Biochem. Biophys. Res. Commun. 2015, 458, 739-744. [CrossRef] [PubMed]

52. Carvalho-Santos, Z.; Machado, P.; Branco, P.; Tavares-Cadete, F.; Rodrigues-Martins, A.; Pereira-Leal, J.B.; Bettencourt-Dias, M. Stepwise evolution of the centriole-assembly pathway. J. Cell Sci. 2010, 123, 1414-1426. [CrossRef] [PubMed]

53. Zhu, C.; Dixit, R. Functions of the arabidopsis kinesin superfamily of microtubule-based motor proteins. Protoplasma 2012, 249, 887-899. [CrossRef] [PubMed]

54. Vanstraelen, M.; Inze, D.; Geelen, D. Mitosis-specific kinesins in arabidopsis. Trends Plant Sci. 2006, 11, 167-175. [CrossRef] [PubMed]

55. Wickstead, B.; Gull, K. Dyneins across eukaryotes: A comparative genomic analysis. Traffic 2007, 8, 1708-1721. [CrossRef] [PubMed]

56. Kandasamy, M.K.; Deal, R.B.; McKinney, E.C.; Meagher, R.B. Plant actin-related proteins. Trends Plant Sci. 2004, 9, 196-202. [CrossRef] [PubMed]

57. Vos, J.W.; Pieuchot, L.; Evrard, J.L.; Janski, N.; Bergdoll, M.; de Ronde, D.; Perez, L.H.; Sardon, T.; Vernos, I.; Schmit, A.C. The plant tpx2 protein regulates prospindle assembly before nuclear envelope breakdown. Plant Cell 2008, 20, 2783-2797. [CrossRef] [PubMed]

58. Liu, B.; Joshi, H.C.; Wilson, T.J.; Silflow, C.D.; Palevitz, B.A.; Snustad, D.P. Gamma-tubulin in arabidopsis: Gene sequence, immunoblot, and immunofluorescence studies. Plant Cell 1994, 6, 303-314. [CrossRef] [PubMed]

59. Kong, Z.; Hotta, T.; Lee, Y.R.; Horio, T.; Liu, B. The \{gamma\}-tubulin complex protein gcp4 is required for organizing functional microtubule arrays in arabidopsis thaliana. Plant Cell 2010, 22, 191-204. [CrossRef] [PubMed]

60. Zeng, C.J.; Lee, Y.R.; Liu, B. The wd40 repeat protein nedd1 functions in microtubule organization during cell division in arabidopsis thaliana. Plant Cell 2009, 21, 1129-1140. [CrossRef] [PubMed]

61. Batzenschlager, M.; Lermontova, I.; Schubert, V.; Fuchs, J.; Berr, A.; Koini, M.A.; Houlne, G.; Herzog, E.; Rutten, T.; Alioua, A.; et al. Arabidopsis mzt1 homologs gip1 and gip2 are essential for centromere architecture. Proc. Natl. Acad. Sci. USA 2015, 112, 8656-8660. [CrossRef] [PubMed]

62. Nakamura, M.; Yagi, N.; Kato, T.; Fujita, S.; Kawashima, N.; Ehrhardt, D.W.; Hashimoto, T. Arabidopsis gcp3-interacting protein $1 /$ mozart 1 is an integral component of the gamma-tubulin-containing microtubule nucleating complex. Plant J. 2012, 71, 216-225. [CrossRef] [PubMed]

63. Janski, N.; Masoud, K.; Batzenschlager, M.; Herzog, E.; Evrard, J.L.; Houlne, G.; Bourge, M.; Chaboute, M.E.; Schmit, A.C. The gcp3-interacting proteins gip1 and gip2 are required for gamma-tubulin complex protein localization, spindle integrity, and chromosomal stability. Plant Cell 2012, 24, 1171-1187. [CrossRef] [PubMed]

64. Lin, T.C.; Neuner, A.; Schiebel, E. Targeting of gamma-tubulin complexes to microtubule organizing centers: Conservation and divergence. Trends Cell Biol. 2015, 25, 296-307. [CrossRef] [PubMed] 
65. Hotta, T.; Kong, Z.; Ho, C.M.; Zeng, C.J.; Horio, T.; Fong, S.; Vuong, T.; Lee, Y.R.; Liu, B. Characterization of the arabidopsis augmin complex uncovers its critical function in the assembly of the acentrosomal spindle and phragmoplast microtubule arrays. Plant Cell 2012, 24, 1494-1509. [CrossRef] [PubMed]

66. Kawaguchi, S.; Zheng, Y. Characterization of a drosophila centrosome protein cp309 that shares homology with kendrin and cg-nap. Mol. Biol. Cell 2004, 15, 37-45. [CrossRef] [PubMed]

67. Kawamura, E.; Wasteneys, G.O. Mor1, the arabidopsis thaliana homologue of xenopus map215, promotes rapid growth and shrinkage, and suppresses the pausing of microtubules in vivo. J. Cell Sci. 2008, 121, 4114-4123. [CrossRef] [PubMed]

68. Jiang, K.; Hua, S.; Mohan, R.; Grigoriev, I.; Yau, K.W.; Liu, Q.; Katrukha, E.A.; Altelaar, A.F.; Heck, A.J.; Hoogenraad, C.C.; et al. Microtubule minus-end stabilization by polymerization-driven camsap deposition. Dev. Cell 2014, 28, 295-309. [CrossRef] [PubMed]

69. Hamada, T.; Nagasaki-Takeuchi, N.; Kato, T.; Fujiwara, M.; Sonobe, S.; Fukao, Y.; Hashimoto, T. Purification and characterization of novel microtubule-associated proteins from arabidopsis cell suspension cultures. Plant Physiol. 2013, 163, 1804-1816. [CrossRef] [PubMed]

70. Hirano, T. Condensins: Organizing and segregating the genome. Curr. Biol. 2005, 15, R265-R275. [CrossRef] [PubMed]

71. Siddiqui, N.U. Mutations in arabidopsis condensin genes disrupt embryogenesis, meristem organization and segregation of homologous chromosomes during meiosis. Development 2003, 130, 3283-3295. [CrossRef] [PubMed]

72. Fujimoto, S.; Yonemura, M.; Matsunaga, S.; Nakagawa, T.; Uchiyama, S.; Fukui, K. Characterization and dynamic analysis of arabidopsis condensin subunits, atcap-h and atcap-h2. Planta 2005, 222, 293-300. [CrossRef] [PubMed]

73. Siddiqui, N.U.; Rusyniak, S.; Hasenkampf, C.A.; Riggs, C.D. Disruption of the arabidopsis smc4 gene, atcap-c, compromises gametogenesis and embryogenesis. Planta 2006, 223, 990-997. [CrossRef] [PubMed]

74. Bhatt, A.M.; Lister, C.; Page, T.; Fransz, P.; Findlay, K.; Jones, G.H.; Dickinson, H.G.; Dean, C. The dif1 gene of arabidopsis is required for meioticchromosome segregation and belongs to the $\mathrm{rec} 8 / \mathrm{rad} 21$ cohesin gene family. Plant J. 1999, 19, 463-472. [CrossRef] [PubMed]

75. Schubert, V.; Weissleder, A.; Ali, H.; Fuchs, J.; Lermontova, I.; Meister, A.; Schubert, I. Cohesin gene defects may impair sister chromatid alignment and genome stability in arabidopsis thaliana. Chromosoma 2009, 118, 591-605. [CrossRef] [PubMed]

76. Sebastian, J.; Ravi, M.; Andreuzza, S.; Panoli, A.P.; Marimuthu, M.P.; Siddiqi, I. The plant adherin atscc 2 is required for embryogenesis and sister-chromatid cohesion during meiosis in arabidopsis. Plant J. 2009, 59, 1-13. [CrossRef] [PubMed]

77. Singh, D.K.; Andreuzza, S.; Panoli, A.P.; Siddiqi, I. Atctf7 is required for establishment of sister chromatid cohesion and association of cohesin with chromatin during meiosis in arabidopsis. BMC Plant Biol. 2013. [CrossRef] [PubMed]

78. Ladurner, R.; Kreidl, E.; Ivanov, M.P.; Ekker, H.; Idarraga-Amado, M.H.; Busslinger, G.A.; Wutz, G.; Cisneros, D.A.; Peters, J.M. Sororin actively maintains sister chromatid cohesion. EMBO J. 2016, 35, 635-653. [CrossRef] [PubMed]

79. Zamariola, L.; De Storme, N.; Tiang, C.L.; Armstrong, S.J.; Franklin, F.C.; Geelen, D. Sgo1 but not sgo2 is required for maintenance of centromere cohesion in arabidopsis thaliana meiosis. Plant Reprod. 2013, 26, 197-208. [CrossRef] [PubMed]

80. Kirioukhova, O.; Johnston, A.J.; Kleen, D.; Kagi, C.; Baskar, R.; Moore, J.M.; Baumlein, H.; Gross-Hardt, R.; Grossniklaus, U. Female gametophytic cell specification and seed development require the function of the putative arabidopsis incenp ortholog wyrd. Development 2011, 138, 3409-3420. [CrossRef] [PubMed]

81. Lermontova, I.; Kuhlmann, M.; Friedel, S.; Rutten, T.; Heckmann, S.; Sandmann, M.; Demidov, D.; Schubert, V.; Schubert, I. Arabidopsis kinetochore null2 is an upstream component for centromeric histone h3 variant cenh3 deposition at centromeres. Plant Cell 2013, 25, 3389-3404. [CrossRef] [PubMed]

82. Talbert, P.B.; Masuelli, R.; Tyagi, A.P.; Comai, L.; Henikoff, S. Centromeric localization and adaptive evolution of an arabidopsis histone h3 variant. Plant Cell 2002, 14, 1053-1066. [CrossRef] [PubMed]

83. Ogura, Y.; Shibata, F.; Sato, H.; Murata, M. Characterization of a cenp-c homolog in arabidopsis thaliana. Genes Genet. Syst. 2004, 79, 139-144. [CrossRef] [PubMed] 
84. Dangel, N.J.; Knoll, A.; Puchta, H. Mhf1 plays fanconi anaemia complementation group M protein (fancm)-dependent and fancm-independent roles in DNA repair and homologous recombination in plants. Plant J. 2014, 78, 822-833. [CrossRef] [PubMed]

85. Girard, C.; Crismani, W.; Froger, N.; Mazel, J.; Lemhemdi, A.; Horlow, C.; Mercier, R. Fancm-associated proteins mhf1 and mhf2, but not the other fanconi anemia factors, limit meiotic crossovers. Nucleic Acids Res. 2014, 42, 9087-9095. [CrossRef] [PubMed]

86. Sato, H.; Shibata, F.; Murata, M. Characterization of a mis12 homologue in arabidopsis thaliana. Chromosome Res. 2005, 13, 827-834. [CrossRef] [PubMed]

87. Tromer, E.; Snel, B.; Kops, G.J. Widespread recurrent patterns of rapid repeat evolution in the kinetochore scaffold knl1. Genome Biol. Evol. 2015, 7, 2383-2393. [CrossRef] [PubMed]

88. Caillaud, M.C.; Paganelli, L.; Lecomte, P.; Deslandes, L.; Quentin, M.; Pecrix, Y.; Le Bris, M.; Marfaing, N.; Abad, P.; Favery, B. Spindle assembly checkpoint protein dynamics reveal conserved and unsuspected roles in plant cell division. PLoS ONE 2009, 4, e6757. [CrossRef] [PubMed]

89. Wang, M.; Tang, D.; Luo, Q.; Jin, Y.; Shen, Y.; Wang, K.; Cheng, Z. Brk1, a bub1-related kinase, is essential for generating proper tension between homologous kinetochores at metaphase i of rice meiosis. Plant Cell 2012, 24, 4961-4973. [CrossRef] [PubMed]

90. de Oliveira, E.A.; Romeiro, N.C.; Ribeiro Eda, S.; Santa-Catarina, C.; Oliveira, A.E.; Silveira, V.; de Souza Filho, G.A.; Venancio, T.M.; Cruz, M.A. Structural and functional characterization of the protein kinase mps1 in arabidopsis thaliana. PLoS ONE 2012, 7, e45707. [CrossRef] [PubMed]

91. Xu, X.M.; Rose, A.; Muthuswamy, S.; Jeong, S.Y.; Venkatakrishnan, S.; Zhao, Q.; Meier, I. Nuclear pore anchor, the arabidopsis homolog of $\mathrm{tpr} / \mathrm{mlp} 1 / \mathrm{mlp} 2 /$ megator, is involved in mrna export and sumo homeostasis and affects diverse aspects of plant development. Plant Cell 2007, 19, 1537-1548. [CrossRef] [PubMed]

92. Starr, D.A.; Williams, B.C.; Li, Z.; Etemad-Moghadam, B.; Dawe, R.K.; Goldberg, M.L. Conservation of the centromere/kinetochore protein zw10. J. Cell Biol. 1997, 138, 1289-1301. [CrossRef] [PubMed]

93. McKinley, K.L.; Cheeseman, I.M. The molecular basis for centromere identity and function. Nat. Rev. Mol. Cell Biol. 2016, 17, 16-29. [CrossRef] [PubMed]

94. Drykova, D.; Cenklova, V.; Sulimenko, V.; Volc, J.; Draber, P.; Binarova, P. Plant gamma-tubulin interacts with alphabeta-tubulin dimers and forms membrane-associated complexes. Plant Cell 2003, 15, 465-480. [CrossRef] [PubMed]

95. Murata, T.; Sonobe, S.; Baskin, T.I.; Hyodo, S.; Hasezawa, S.; Nagata, T.; Horio, T.; Hasebe, M. Microtubule-dependent microtubule nucleation based on recruitment of gamma-tubulin in higher plants. Nat. Cell Biol. 2005, 7, 961-968. [CrossRef] [PubMed]

96. Azimzadeh, J.; Nacry, P.; Christodoulidou, A.; Drevensek, S.; Camilleri, C.; Amiour, N.; Parcy, F.; Pastuglia, M.; Bouchez, D. Arabidopsis tonneau1 proteins are essential for preprophase band formation and interact with centrin. Plant Cell 2008, 20, 2146-2159. [CrossRef] [PubMed]

97. Hodges, M.E.; Wickstead, B.; Gull, K.; Langdale, J.A. The evolution of land plant cilia. New Phytol. 2012, 195, 526-540. [CrossRef] [PubMed]

98. Kardon, J.R.; Vale, R.D. Regulators of the cytoplasmic dynein motor. Nat. Rev. Mol. Cell Biol. 2009, 10, 854-865. [CrossRef] [PubMed]

99. Lawrence, C.J.; Morris, N.R.; Meagher, R.B.; Dawe, R.K. Dyneins have run their course in plant lineage. Traffic 2001, 2, 362-363. [CrossRef] [PubMed]

100. Rapali, P.; Szenes, A.; Radnai, L.; Bakos, A.; Pal, G.; Nyitray, L. Dynll/lc8: A light chain subunit of the dynein motor complex and beyond. FEBS J. 2011, 278, 2980-2996. [CrossRef] [PubMed]

101. Endow, S.A. Determinants of molecular motor directionality. Nat. Cell Biol. 1999, 1, E163-E167. [CrossRef] [PubMed]

102. Jonsson, E.; Yamada, M.; Vale, R.D.; Goshima, G. Clustering of a kinesin-14 motor enables processive retrograde microtubule-based transport in plants. Nat. Plants 2015, 1. [CrossRef] [PubMed]

103. Furuta, K.; Furuta, A.; Toyoshima, Y.Y.; Amino, M.; Oiwa, K.; Kojima, H. Measuring collective transport by defined numbers of processive and nonprocessive kinesin motors. Proc. Natl. Acad. Sci. USA 2013, 110, 501-506. [CrossRef] [PubMed]

104. Goshima, G.; Nedelec, F.; Vale, R.D. Mechanisms for focusing mitotic spindle poles by minus end-directed motor proteins. J. Cell Biol. 2005, 171, 229-240. [CrossRef] [PubMed]

105. Hyams, J.S.; Campbell, C.J. Widespread absence of outer dynein arms in the spermatozoids of lower plants. Cell Biol. Int. Rep. 1985, 9, 841-848. [CrossRef] 
106. Komaki, S.; Schnittger, A. The spindle checkpoint in plants-a green variation over a conserved theme? Curr. Opin. Plant Biol. 2016, 34, 84-91. [CrossRef] [PubMed]

107. Przewloka, M.R.; Zhang, W.; Costa, P.; Archambault, V.; D'Avino, P.P.; Lilley, K.S.; Laue, E.D.; McAinsh, A.D.; Glover, D.M. Molecular analysis of core kinetochore composition and assembly in drosophila melanogaster. PLoS ONE 2007, 2, e478. [CrossRef] [PubMed]

108. Miki, T.; Nishina, M.; Goshima, G. Rnai screening identifies the armadillo repeat-containing kinesins responsible for microtubule-dependent nuclear positioning in physcomitrella patens. Plant Cell Physiol. 2015, 56, 737-749. [CrossRef] [PubMed]

109. Binarova, P.; Cenklova, V.; Prochazkova, J.; Doskocilova, A.; Volc, J.; Vrlik, M.; Bogre, L. Gamma-Tubulin is essential for acentrosomal microtubule nucleation and coordination of late mitotic events in arabidopsis. Plant Cell 2006, 18, 1199-1212. [CrossRef] [PubMed]

110. Pastuglia, M.; Azimzadeh, J.; Goussot, M.; Camilleri, C.; Belcram, K.; Evrard, J.L.; Schmit, A.C.; Guerche, P.; Bouchez, D. Gamma-Tubulin is essential for microtubule organization and development in arabidopsis. Plant Cell 2006, 18, 1412-1425. [CrossRef] [PubMed]

111. Goshima, G.; Mayer, M.; Zhang, N.; Stuurman, N.; Vale, R.D. Augmin: A protein complex required for centrosome-independent microtubule generation within the spindle. J. Cell Biol. 2008, 181, 421-429. [CrossRef] [PubMed]

112. Liu, T.; Tian, J.; Wang, G.; Yu, Y.; Wang, C.; Ma, Y.; Zhang, X.; Xia, G.; Liu, B.; Kong, Z. Augmin triggers microtubule-dependent microtubule nucleation in interphase plant cells. Curr. Biol. 2014, 24, 2708-2713. [CrossRef] [PubMed]

113. Bannigan, A.; Scheible, W.R.; Lukowitz, W.; Fagerstrom, C.; Wadsworth, P.; Somerville, C.; Baskin, T.I. A conserved role for kinesin-5 in plant mitosis. J. Cell Sci. 2007, 120, 2819-2827. [CrossRef] [PubMed]

114. Miki, T.; Naito, H.; Nishina, M.; Goshima, G. Endogenous localizome identifies 43 mitotic kinesins in a plant cell. Proc. Natl. Acad. Sci. USA 2014, 111, E1053-E1061. [CrossRef] [PubMed]

115. Chen, C.; Marcus, A.; Li, W.; Hu, Y.; Calzada, J.P.; Grossniklaus, U.; Cyr, R.J.; Ma, H. The arabidopsis atk1 gene is required for spindle morphogenesis in male meiosis. Development 2002, 129, 2401-2409. [PubMed]

116. Ambrose, J.C.; Li, W.; Marcus, A.; Ma, H.; Cyr, R. A minus-end-directed kinesin with plus-end tracking protein activity is involved in spindle morphogenesis. Mol. Biol. Cell 2005, 16, 1584-1592. [CrossRef] [PubMed]

117. Marcus, A.I.; Li, W.; Ma, H.; Cyr, R.J. A kinesin mutant with an atypical bipolar spindle undergoes normal mitosis. Mol. Biol. Cell 2003, 14, 1717-1726. [CrossRef] [PubMed]

118. Ito, A.; Goshima, G. Microcephaly protein asp focuses the minus ends of spindle microtubules at the pole and within the spindle. J. Cell Biol. 2015, 211, 999-1009. [CrossRef] [PubMed]

119. Kawamura, E.; Himmelspach, R.; Rashbrooke, M.C.; Whittington, A.T.; Gale, K.R.; Collings, D.A.; Wasteneys, G.O. Microtubule organization 1 regulates structure and function of microtubule arrays during mitosis and cytokinesis in the arabidopsis root. Plant Physiol. 2006, 140, 102-114. [CrossRef] [PubMed]

120. Komaki, S.; Abe, T.; Coutuer, S.; Inze, D.; Russinova, E.; Hashimoto, T. Nuclear-localized subtype of end-binding 1 protein regulates spindle organization in arabidopsis. J. Cell Sci. 2010, 123, 451-459. [CrossRef] [PubMed]

121. Maiato, H.; Khodjakov, A.; Rieder, C.L. Drosophila clasp is required for the incorporation of microtubule subunits into fluxing kinetochore fibres. Nat. Cell Biol. 2005, 7, 42-47. [CrossRef] [PubMed]

122. Ambrose, J.C.; Shoji, T.; Kotzer, A.M.; Pighin, J.A.; Wasteneys, G.O. The arabidopsis clasp gene encodes a microtubule-associated protein involved in cell expansion and division. Plant Cell 2007, 19, 2763-2775. [CrossRef] [PubMed]

123. Rogers, G.C.; Rogers, S.L.; Sharp, D.J. Spindle microtubules in flux. J. Cell Sci. 2005, 118, 1105-1116. [CrossRef] [PubMed]

124. Dhonukshe, P.; Vischer, N.; Gadella, T.W., Jr. Contribution of microtubule growth polarity and flux to spindle assembly and functioning in plant cells. J. Cell Sci. 2006, 119, 3193-3205. [CrossRef] [PubMed]

125. Otegui, M.S.; Verbrugghe, K.J.; Skop, A.R. Midbodies and phragmoplasts: Analogous structures involved in cytokinesis. Trends Cell Biol. 2005, 15, 404-413. [CrossRef] [PubMed]

126. Duellberg, C.; Fourniol, F.J.; Maurer, S.P.; Roostalu, J.; Surrey, T. End-Binding proteins and ase1/prc1 define local functionality of structurally distinct parts of the microtubule cytoskeleton. Trends Cell. Biol 2013, 23, 54-63. [CrossRef] [PubMed] 
127. Kosetsu, K.; de Keijzer, J.; Janson, M.E.; Goshima, G. Microtubule-associated protein65 is essential for maintenance of phragmoplast bipolarity and formation of the cell plate in physcomitrella patens. Plant Cell 2013, 25, 4479-4492. [CrossRef] [PubMed]

128. Ho, C.M.; Hotta, T.; Guo, F.; Roberson, R.W.; Lee, Y.R.; Liu, B. Interaction of antiparallel microtubules in the phragmoplast is mediated by the microtubule-associated protein map65-3 in arabidopsis. Plant Cell 2011, 23, 2909-2923. [CrossRef] [PubMed]

129. Muller, S.; Smertenko, A.; Wagner, V.; Heinrich, M.; Hussey, P.J.; Hauser, M.T. The plant microtubule-associated protein atmap65-3/ple is essential for cytokinetic phragmoplast function. Curr. Biol. 2004, 14, 412-417. [CrossRef] [PubMed]

130. Sasabe, M.; Kosetsu, K.; Hidaka, M.; Murase, A.; Machida, Y. Arabidopsis thaliana map65-1 and map65-2 function redundantly with map65-3/pleiade in cytokinesis downstream of mpk4. Plant Signal Behav. 2011, 6, 743-747. [CrossRef] [PubMed]

131. Hiwatashi, Y.; Obara, M.; Sato, Y.; Fujita, T.; Murata, T.; Hasebe, M. Kinesins are indispensable for interdigitation of phragmoplast microtubules in the moss physcomitrella patens. Plant Cell 2008, 20, 3094-3106. [CrossRef] [PubMed]

132. Archambault, V.; Carmena, M. Polo-Like kinase-activating kinases: Aurora a, aurora b and what else? Cell Cycle 2012, 11, 1490-1495. [CrossRef] [PubMed]

133. Hu, C.K.; Ozlu, N.; Coughlin, M.; Steen, J.J.; Mitchison, T.J. Plk1 negatively regulates prc1 to prevent premature midzone formation before cytokinesis. Mol. Biol. Cell 2012, 23, 2702-2711. [CrossRef] [PubMed]

134. Van Damme, D.; De Rybel, B.; Gudesblat, G.; Demidov, D.; Grunewald, W.; De Smet, I.; Houben, A.; Beeckman, T.; Russinova, E. Arabidopsis alpha aurora kinases function in formative cell division plane orientation. Plant Cell 2011, 23, 4013-4024. [CrossRef] [PubMed]

135. Sasabe, M.; Machida, Y. Regulation of organization and function of microtubules by the mitogen-activated protein kinase cascade during plant cytokinesis. Cytoskeleton 2012, 69, 913-918. [CrossRef] [PubMed]

136. Sasabe, M.; Soyano, T.; Takahashi, Y.; Sonobe, S.; Igarashi, H.; Itoh, T.J.; Hidaka, M.; Machida, Y. Phosphorylation of ntmap65-1 by a map kinase down-regulates its activity of microtubule bundling and stimulates progression of cytokinesis of tobacco cells. Genes Dev. 2006, 20, 1004-1014. [CrossRef] [PubMed]

137. Panteris, E.; Adamakis, I.D.; Voulgari, G.; Papadopoulou, G. A role for katanin in plant cell division: Microtubule organization in dividing root cells of fra2 and lue1arabidopsis thaliana mutants. Cytoskeleton 2011, 68, 401-413. [CrossRef] [PubMed]

138. Murata, T.; Sano, T.; Sasabe, M.; Nonaka, S.; Higashiyama, T.; Hasezawa, S.; Machida, Y.; Hasebe, M. Mechanism of microtubule array expansion in the cytokinetic phragmoplast. Nat. Commun. 2013. [CrossRef] [PubMed]

139. Collonnier, C.; Epert, A.; Mara, K.; Maclot, F.; Guyon-Debast, A.; Charlot, F.; White, C.; Schaefer, D.G.; Nogue, F. Crispr-cas9-mediated efficient directed mutagenesis and rad51-dependent and rad51-independent gene targeting in the moss physcomitrella patens. Plant Biotechnol. J. 2016. [CrossRef]

140. Sugano, S.S.; Shirakawa, M.; Takagi, J.; Matsuda, Y.; Shimada, T.; Hara-Nishimura, I.; Kohchi, T. Crispr/cas9-mediated targeted mutagenesis in the liverwort marchantia polymorpha 1. Plant Cell. Physiol. 2014, 55, 475-481. [CrossRef] [PubMed]

141. Ishizaki, K.; Nishihama, R.; Yamato, K.T.; Kohchi, T. Molecular genetic tools and techniques for marchantia polymorpha research. Plant Cell Physiol. 2016, 57, 262-270. [CrossRef] [PubMed]

142. Nakaoka, Y.; Kimura, A.; Tani, T.; Goshima, G. Cytoplasmic nucleation and atypical branching nucleation generate endoplasmic microtubules in physcomitrella patens. Plant Cell 2015, 27, 228-242. [CrossRef] [PubMed]

143. Kiyomitsu, T. Mechanisms of daughter cell-size control during cell division. Trends Cell Biol. 2015, 25, 286-295. [CrossRef] [PubMed]

144. Buschmann, H.; Zachgo, S. The evolution of cell division: From streptophyte algae to land plants. Trends Plant Sci. 2016, 21, 872-883. [CrossRef] [PubMed]

(C) 2017 by the authors; licensee MDPI, Basel, Switzerland. This article is an open access article distributed under the terms and conditions of the Creative Commons Attribution (CC BY) license (http:/ / creativecommons.org/licenses/by/4.0/). 